\title{
Pemilihan FinTech Payment untuk Mahasiswa menggunakan Fuzzy Technique For Order Preference by Similarity of Ideal Solution
}

\author{
Syahbaniar Rofiah ${ }^{1,}$, Didik Setiyadi $^{2}$ \\ ${ }^{1}$ Manajemen Informatika; Universitas Bina Insanl; Jl. Siliwangi No 6 Rawa Panjang Bekasi \\ Timur 17114 Indonesia. Telp. (021) 82436886 / (021) 82436 996. Fax. (021) 824009 24; e- \\ mail: rsyahbaniar@gmail.com \\ 2 Teknik Informatika; Universitas Bina Insanl; Jl. Siliwangi No 6 Rawa Panjang Bekasi Timur \\ 17114 Indonesia. Telp. (021) 82436886 / (021) 82436 996. Fax. (021) 824009 24; e-mail: \\ didiksetiyadi@binainsani.ac.id
}

* Korespondensi: e-mail: rsyahbaniar@gmail.com

Diterima: 7 Maret 2020; Review: 12 Maret 2020; Disetujui: 18 Maret 2020

Cara sitasi: Rofiah S, Setiyadi D. 2020. Pemilihan Fintect Payment untuk Mahasiswa menggunakan Fuzzy Technique For Order Preference by Similarity of Ideal Solution. Bina Insani ICT Journal. 7 (1): 13-22.

\begin{abstract}
Abstrak: Pembayaran saat ini beragam macamnya dari pembayaran menggunakan uang tunai, kartu sampai dengan dompet digital. Dompet digital merupakan alat pembayaran yang sah dibawah pengawasan OJK seperti contoh Gopay, OVO, Dana, Link aja, Shopepay dan lain-lain. Pemilihan dompet digital sangat berperan bagi ekonomi mahasiswa, semakin tinggi tingkat ekonomi mahasiswa pemilihan dompet digital pun berubah. Penelitian ini untuk pemilihan fintech payment yaitu Gopay, OVO, Dana, Link Aja dan Shopepay untuk Mahasiswa menggunakan Metode Fuzzy Technique For Order Preference by Similarity of Ideal Solution (TOPSIS). Hasil dari penelitian ini Gopay mempunyai nilai tertinggi dengan angka 0,9220, kemudian rangking ke dua OVO 0,8435, dan yang ketiga 0,5910 untuk shopepay dari hasil tersebut Gopay dapat digunakan sebagai rekomendasi mahasiswa untuk bertransaksi.
\end{abstract}

Kata kunci: dompet digital, dana, gopay, OVO, shopepay

\begin{abstract}
Abstract: Current payments vary from cash, card to digital wallet payments. Digital wallet is a legal payment instrument under the supervision of OJK, for example Gopay, OVO, Funds, Link only, Shopepay and others. The choice of digital wallet plays an important role for the student economy, the higher the economic level of students the selection of digital wallet changes. This research is for fintech payment selection namely Gopay, OVO, Funds, Link Aja and Shopepay for Students using the Fuzzy Technique Method for Order Preference by Similarity of Ideal Solution (TOPSIS). The results of this study Gopay has the highest value with a number of 0.9220 , then ranked second OVO 0.8435 , and the third 0.5910 for shopepay from these results Gopay can be used as a recommendation for students to transact.
\end{abstract}

Keywords: digital wallet, dana, gopay, OVO, shopepay

\section{Pendahuluan}

Ekonomi adalah ilmu tentang perilaku dan tindakan manusia untuk memenuhi kebutuhan hidupnya yang bervariasi dan berkembang dengan memanfaatkan sumber daya yang ada melalui pilihan-pilihan kegiatan produksi, konsumsi, dan atau produksi. Berbagai fenomena empirik ekonomi saat ini, yang ditandai pesatnya perkembangan IPTEK, pada akhirnya mendorong perubahan metode produksi, konsumsi, dan atau distribusi serta lahirnya regulasi 
baru ini berdampak pada perubahan sistem tata kelola Perbankan dan Industri jasa keuangan. Lahirnya regulasi baru ini berdampak pada perubahan sistem pengaturan dan pengawasan Lembaga keuangan Bank (LKB) dan dan lembaga Keuangan Bukan Bank (LKBB) di Indonesia. Atas dasar itu lahir Undang (UU) No 21 tahun 2011 tentang Otoritas Jasa keuangan (OJK) yang mengatur dan melandasi pelaksanaan fungsi pengawasan dan pengaturan berbagai lembaga jasa keuangan [1].

Pembayaran saat ini beragam macamnya dari pembayaran menggunakan uang tunai, kartu sampai dengan dompet digital. Dompet digital merupakan alat pembayaran yang sah dibawah pengawasan Otoritas Jasa Keuangan (OJK) seperti contoh Dana, OVO, Gopay, Shopepay dan lain-lain. masyarakat dapat memilih pembayaran sesuai dengan tingkat ekonomi dan minat dari pengguna itu sendiri. Teknologi yang berkembang dan terkoneksi internet dapat memaksimalkan penggunaan dari dompet digital. Semakin besar jangkauan dalam pembayaran di berbagai kota dapat memudahkan pengguna untuk bertransaksi dengan lancar.

Perdagangan selalu melibatkan pembayar dan penerima pembayaran yang menukar uang dengan barang atau jasa, dan setidaknya satu lembaga keuangan yang menghubungkan bit dengan uang. Dalam sebagian besar sistem pembayaran yang ada, peran yang terakhir dibagi menjadi dua bagian penerbit (digunakan oleh pembayar) dan pengakuisisi (digunakan oleh penerima pembayaran). Sedangkan pembayaran elektronik dari pembayar ke penerima pembayaran dilaksanakan oleh aliran uang riil dari pembayaran melalui penerbit dan pengakuisisi ke penerima pembayaran [2].

Pembayaran digital merupakan salah satu layanan keuangan ritel yang paling banyak digunakan sehari-hari. Layanan ini meningkatkan pengalaman bagi pelanggan yang mencari pengalaman pembayaran yang efesien dalam hal kecepatan, kenyamanan dan aksesibilitas multi saluran. Model bisnis pembayaran memiliki 2(dua) teknik pembayaran yang pertama, pembayaran konsumen dan ritel yang kedua, pembayaran grosir dan perusahaan [3].

Fintech payment adalah aplikasi smart (platform) yang diantara bentuknya adalah fintech payment cash (e-money) dan fintech payment points. fintech payment cash yaitu uang elektronik yang diakses aplikasi fintech payment dan dapat digunakan untuk berbagai transaksi, seperti pembayaran di merchant rekanan, top up, Cek saldo, bayar jasa tol dan jasa tranportasi online. Sedangkan fintech payment points yaitu loyalty reward yang diperoleh pengguna setiap kali transaksi di merchant [4].

Salah satu contoh kasus Fintech di Indonesia adalah Gopay. Gopay merupakan fitur dari PT Gojek Indonesia yang berfungsi untuk memberikan kemudahan dalam bertransaksi layanan di Gojek tanpa menggunakan uang tunai [5]. Gopay telah hadir di 167 kota dan kabupaten di seluruh Indonesia [6]. Selanjutnya Dana, Link Aja, OVO dan Shopepay merupakan contoh fintech Payment yang digunakan sebagai alternatif penelitian. Sedangkan uang elektronik yang beredar di Indonesia tercantum dalam data Bank Indonesia dari tahun 2013 sampai dengan April tahun 2020 tercatat $\mathrm{Rp} 412.055 .870$ dapat dilihat pada gambar 1 [7].

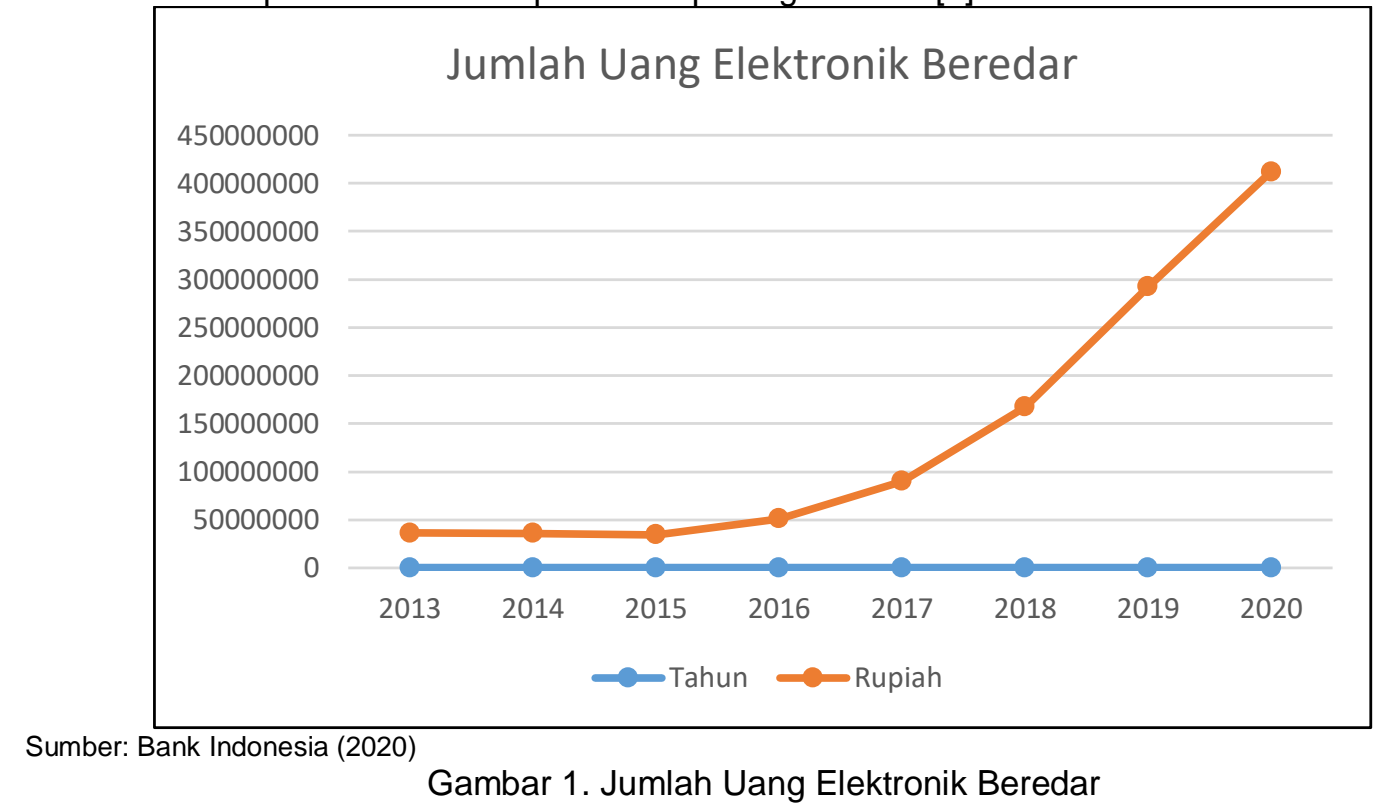


Dengan data pada gambar 1 statistik sistem pembayaran yang digunakan masyarakat menggunakan fintech payment setiap tahun semakin meningkat pada bulan April tahun 2020 mencapai Rp 412.055.870. Dengan banyaknya uang elektronik yang beredar semakin banyak minat dari pengguna untuk bertransaksi secara elektronik atau non tunai. Mahasiswa merupakan salah satu pengguna fintech payment, untuk memaksimalkan transaksi yang digunakan diperlukan penelitian lebih lanjut.

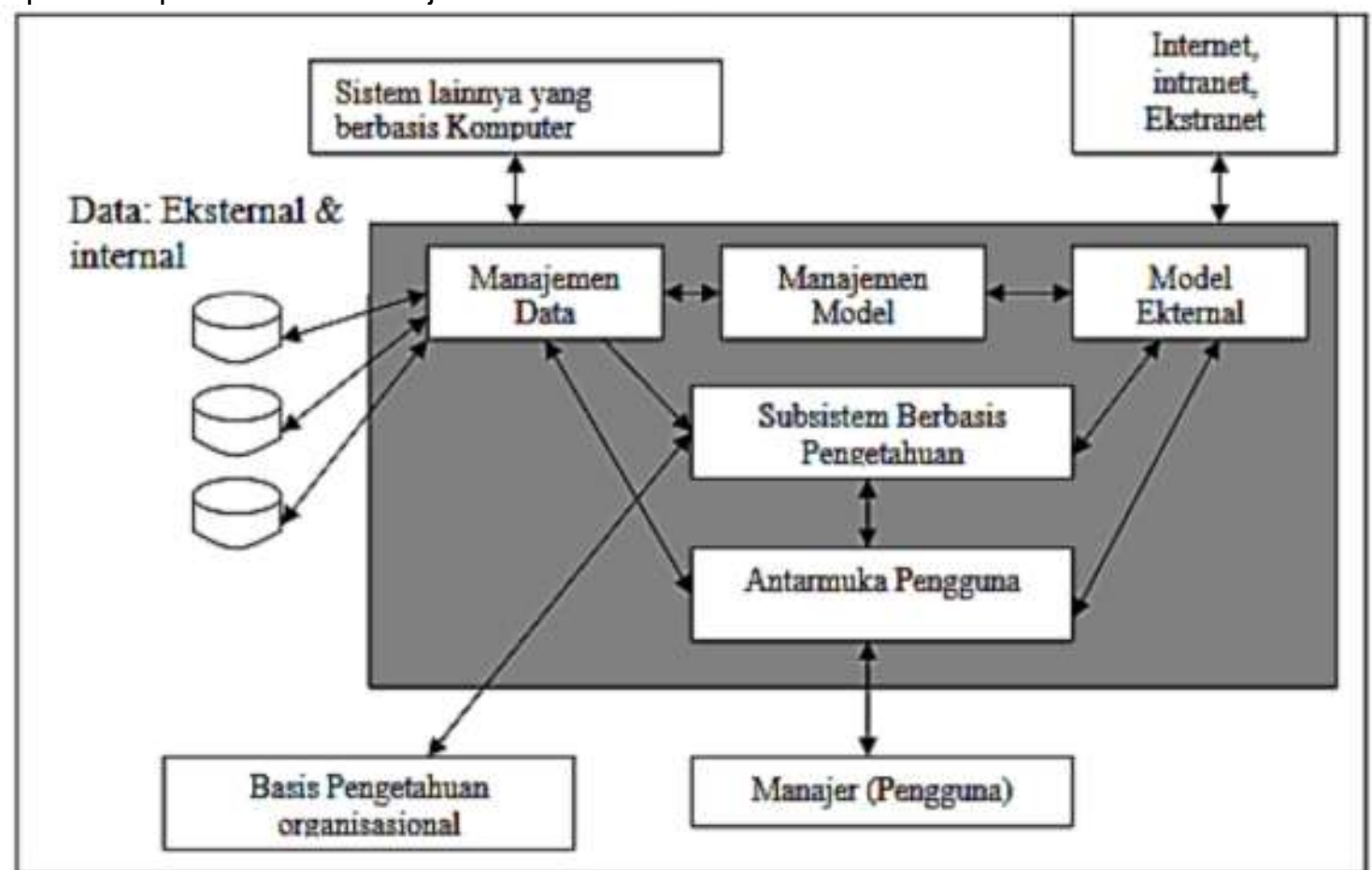

Sumber: Nofriansyah (2014)

Gambar 2. Arsitektur Sistem Pendukung Keputusan

Gambar 2 merupakan arsitektur sistem pendukung keputusan, komponen utama dalam sistem pendukung keputusan adalah, manajemen data berupa sumber data pada basis data dan data dasar, manajemen model berupa data statistik [8].

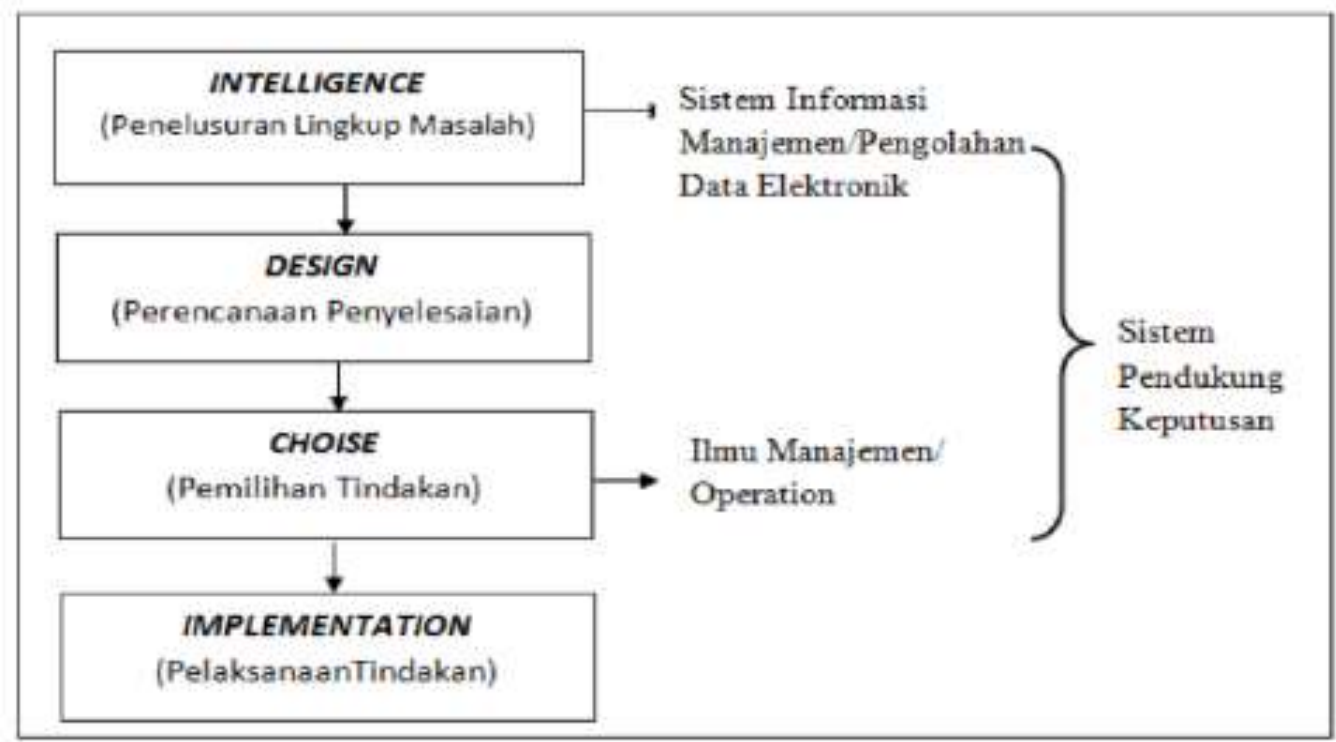

Sumber: Nofriansyah (2014)

Gambar 3. Fase Proses Pengambilan Keputusan 
Gambar 3 merupakan fase proses pengambilan keputusan yang terdiri dari intelegent tahap ini merupakan proses penelusuran pendeteksian dari ruang lingkup problematika secara proses pengenalan masalah. Data masukan diperoleh, diproses dan diuji dalam rangka mengidentifikasi masalah, selanjutnya design tahap ini merupakan proses menemukan, mengembangkan dan menganalisis alternatif tindakan yang bisa dilakukan tahap ini meliputi menguji kelayakan solusi, yang terakhir choice pada tahap ini dilakukan proses pemilihan diantara berbagai alternatif tindakan yang mungkin dijalankan. Hasil pemilihan tersebut kemudian diimplementasikan dalam proses pengambilan keputusan [8].

Pada penelitian sebelumnya terdapat dalam pemilihan Mawapres secara langsung atau tidak langsung dapat mengangkat martabat mahasiswa dan perguruan tingginya. Dalam proses seleksinya melibatkan pertimbangan atau kriteria yang sifatnya crisp : IPK, karya ilmiah, prestasi unggulan dan kemampuan bahasa Inggris. Tetapi dalam kenyataannya kriteria tersebut ada yang bersifat fuzzy dan kesulitan dalam melakukan pengurutan sehingga metode fuzzy TOPSIS sebagai solusi [9]. Hasil pengelolahan data yang dilakukan dapat disimpulkan bahwa penggunaan metode Technique For Order Preference by Similarity of Ideal Solution (TOPSIS) dalam pemilihan supervisor layak untuk digunakan dengan nilai pengujian reliabilitas sebesar $0,993^{*}$ dari maksimum nilai reliabilitas adalah 1 [10].

Tingkat prioritas Perguruan Tinggi di Indonesia dibahas dengan menggunakan metode fuzzy TOPSIS. Alternatif yang memiliki nilai kedekatan (closeness coefficient) terbesar sehingga diperoleh prioritas tertinggi dalam urutan 10 ranking Perguruan Tinggi di Indonesia [11]. Dari beberapa penelitian diatas dapat disimpulkan metode fuzzy Technique For Order Preference by Similarity of Ideal Solution (TOPSIS) menjadi solusi untuk pemilihan fintech payment. This research found that convenience was the strongest factor that influenced the perceived benefit of mobile payment FinTech, especially because mobile payment FinTech user can use financial services easily anytime, and anywhere. Convenience had the strongespositive impact on the perceived benefit, which later increased the mobile payment FinTech. Dapat diartikan penelitian nya menemukan bahwa kenyamanan adalah faktor terkuat yang mempengaruhi manfaat yang dirasakan dari pembayaran mobile FinTech, terutama karena pembayaran mobile FinTech pengguna dapat menggunakan layanan keuangan dengan mudah kapan saja, dan di mana saja. Kenyamanan memiliki dampak positif yang kuat pada manfaat yang dirasakan, yang kemudian meningkatkan pembayaran seluler FinTech niat penggunaan berkelanjutan.

Permasalahan yang terjadi saat ini pada mahasiswa diantaranya yang pertama terdapat payment yang beredar di banyak aplikasi fintech Indonesia sehingga membingungkan dalam memilih yang efektif, yang kedua tingkat keamanan yang belum diketahui oleh mahasiswa dalam bertransaksi non tunai, dan yang ketiga jangkauan dari jaringan fintech payment yang belum tersebar di beberapa kota. Penelitian ini dikhususkan untuk mahasiswa dalam pemilihan fintech payment menggunakan metode fuzzy Technique For Order Preference by Similarity of Ideal Solution (TOPSIS) terdapat 4 alternatif yaitu Gopay, Dana, OVO dan Shopeepay. Tujuan penelitian ini dapat memberikan rekomendasi kepada mahasiswa dalam memilih fintech payment yang efektif.

\section{Metode Penelitian}

Fuzzy Multiple Atribute Decision making (FMADM) adalah suatu metode yang digunakan untuk mencari alternatif optimal dari sejumlah alternatif dengan kriteria tertentu, inti dari Fuzzy MADM adalah menentukan nilai bobot untuk setiap atribut, kemudian dilanjutkan dengan proses perangkingan yang akan menyeleksi alternatif yang sudah diberikan [12].

Dalam pengambilan data menggunakan penelitian survey merupakan pengambilan sampel ilmiah dan desain kuisioner untuk mengukur karakteristik populasi dengan ketepatan statistik langkah ini dilakukan sebagai upaya untuk memberikan jawaban atas pertanyaan seperti "berapa banyak orang yang merasakan suatu hal tertentu?" atau "seberapa sering mereka bertindak dengan penilaian tertentu?", penelitian survey mensyaratkan bahwa respondel adalah sampel yang diambil secara acak artinya bahwa setiap orang dalam populasi memiliki peluang yang sama untuk dijadikan sampel. Sistem acak tidak berarti peneliti sesuka hati menentukan siapa yang dipilih sebagai sampel, sampel yang diambil secara acak tetap harus memenuhi prosedur ilmiah tentang siapa yang terpilih sebagai sampel [13].

Metode penelitian yang digunakan pada penelitian ini adalah fuzzy Technique For Order Preference by Similarity of Ideal Solution (TOPSIS). Teknik pendekatan Fuzzy-Technique for Order Preference by Similarity to Ideal Solution (TOPSIS) meliputi beberapa tahap, antara lain: 
1) Pemberian bobot kepentingan untuk masing-masing kriteria, 2)Pembentukan nominasi matriks berpasangan, 3) Defuzzyfikasi matriks, 4) Normalisasi matriks (1), 5) Pembobotan (2), 6) Pencarian solusi positif (3) dan negatif (4), 7) Pembuatan alternatif positif (5) dan negatif matriks (6), 8) Pencarian nilai preferensi (7), 9)Perankingan. Dalam bentuk rumus keterangan sebagai berikut:

$$
r_{i j}=\frac{x_{i j}}{\sqrt{\sum_{i=1}^{m} x_{i j}^{2}}}
$$

$\mathrm{y}_{\mathrm{ij}}=\mathrm{Wir}_{\mathrm{ij}}$

$\mathrm{A}+=\left(\mathrm{y}_{1}^{+}, \mathrm{y}_{2}{ }^{+}, \ldots, \mathrm{yn}^{+}\right)$

$A^{-}=\left(y_{1}^{-}, y_{2-}, \ldots, y_{n-}\right)$;

Dengan asumsi Solusi ideal Positif dan Negatif

$$
\begin{aligned}
& Y_{j}^{+}=\left\{\begin{array}{l}
\text { Max } y_{i j} ; \text { Jika } j \text { adalah atribut keuntungan } \\
\prod_{i} \text { Min } y_{i j} ; \text { Jika } j \text { adalah atribut beban }
\end{array}\right. \\
& Y_{j}^{+}=\left\{\begin{array}{c}
\text { Min } y_{i j} ; \text { Jika } j \text { adalah atribut keuntungan } \\
M_{i} \text { Max } y_{i j} ; \text { Jika } j \text { adalah atribut beban }
\end{array}\right. \\
& - \\
& D_{i}^{+}=\sqrt{\sum_{i=1}^{m}\left(y_{i}^{+}-y_{i j}\right)^{2}}
\end{aligned}
$$

$$
D_{i}^{-}=\sqrt{\sum_{i=1}^{m}\left(y_{i j}-y_{i}^{-}\right)^{2}}
$$

$$
V_{i}=\begin{gathered}
D_{i}^{-} \\
D_{i}^{-}+D_{i}^{+}
\end{gathered}
$$

Contoh Perhitungan:

$$
\begin{aligned}
V_{i} & =\frac{D_{i^{-}}}{D_{i^{-}+D_{i+}}} \\
& =\frac{0,0844}{0,0844+0,1688} \\
& =\frac{0,0844}{0,2532}=0,3313
\end{aligned}
$$

Alur penelitian digambarkan dalam kerangka pemikiran dapat dilihat pada gambar 4 , yang pertama permasalahan yaitu dalam hal ini objek yang diteliti mahasiswa dan alternatif merupakan aplikasi fintech payment yang sering digunakan mahasiswa, yang kedua pendekatan dalam hal ini metode untuk mengolah data menggunakan pendekatan Fuzzy-Technique for Order Preference by Similarity to Ideal Solution (TOPSIS) sebelumnya telah dijelaskan dalam rumus 1 sampai dengan 7 maupun range dalam tabel 1 pengukuran parameter.

Yang terakhir merupakan implementasi Pemilihan Fintech Payment untuk Mahasiswa menggunakan Fuzzy Technique For Order Preference by Similarity of Ideal Solution (TOPSIS). Dalam proses pengolahan data melalui beberapa tahapan, yang pertama menyebarkan kuisioner kepada 12 mahasiswa kemudian data tersebut diolah kedalam bentuk himpunan fuzzy yang berada pada tabel 1 pengukuran parameter. Yang kedua data tersebut akan diolah kembali dalam 
bobot kepentingan yang terdapat pada tabel 2 bobot kepentingan variabel. Yang ketiga data tersebut akan diolah kedalam nominasi matrik dan selanjutnya akan diolah sesuai dengan tahapan metode TOPSIS.

\section{Permasalahan}

1. Kurang efektif dalam bertransaksi non tunai bagi mahasiswa sehingga menginstal lebih dari 1 aplikasi fintech payment

2. Kurangnya pengetahuan mahasiswa dalam memilih fintech payment dari segi keamanan

3. Belum tersedianya informasi bagi mahasiswa dalam hal jangkauan jaringan aplikasi fintech payment

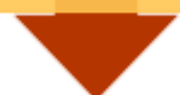

\section{Pendekatan}

Fuzzy Technique For Order Preference by Similarity of Ideal Solution (TOPSIS)

\section{Implementasion}

Pemilihan Fintech Payment untuk Mahasiswa menggunakan Fuzzy Technique For Order Preference by Similarity of Ideal Solution (TOPSIS)

Sumber: Hasil Penelitian (2020)

\section{Gambar 4. Kerangka Penelitian}

\section{Hasil dan Pembahasan}

.Pembahasan dimulai dari menentukan data variabel, pengukuran parameter dalam range bilangan fuzzy dan rating kepentingan setiap variabel dapat dilihat pada tabel 1 dan tabel 2.

\begin{tabular}{|c|c|c|c|}
\hline Variabel & Nama Himpunan Fuzzy & Score & Range \\
\hline \multirow{5}{*}{ Aplikasi (C1) } & Rendah & 0,2 & 1 \\
\hline & Kurang & 0,4 & 2 \\
\hline & Cukup Baik & 0,6 & 3 \\
\hline & Baik & 0,8 & 4 \\
\hline & Sangat Baik & 1 & 5 \\
\hline \multirow{5}{*}{ Jaringan Merchant (C2) } & Rendah & 0,2 & 1 \\
\hline & Kurang & 0,4 & 2 \\
\hline & Cukup Baik & 0,6 & 3 \\
\hline & Baik & 0,8 & 4 \\
\hline & Sangat Baik & 1 & 5 \\
\hline \multirow{5}{*}{ Promosi (C3) } & Rendah & 0,2 & 1 \\
\hline & Kurang & 0,4 & 2 \\
\hline & Cukup Baik & 0,6 & 3 \\
\hline & Baik & 0,8 & 4 \\
\hline & Sangat Baik & 1 & 5 \\
\hline \multirow{5}{*}{$\begin{array}{c}\text { Premium Account Benefit } \\
\text { (C4) }\end{array}$} & Rendah & 0,2 & 1 \\
\hline & Kurang & 0,4 & 2 \\
\hline & Cukup Baik & 0,6 & 3 \\
\hline & Baik & 0,8 & 4 \\
\hline & Sangat Baik & 1 & 5 \\
\hline \multirow{5}{*}{ Userfriendly (C5) } & Rendah & 0,2 & 1 \\
\hline & Kurang & 0,4 & 2 \\
\hline & Cukup Baik & 0,6 & 3 \\
\hline & Baik & 0,8 & 4 \\
\hline & Sangat Baik & 1 & 5 \\
\hline \multirow{3}{*}{ Security (C6) } & Rendah & 0,2 & 1 \\
\hline & Kurang & 0,4 & 2 \\
\hline & Cukup Baik & 0,6 & 3 \\
\hline
\end{tabular}




\begin{tabular}{ccrc}
\hline Variabel & Nama Himpunan Fuzzy & Score & \multicolumn{2}{c}{ Range } \\
\cline { 2 - 4 } & Baik & 0,8 & 4 \\
\cline { 2 - 4 } & Sangat Baik & 1 & 5 \\
\hline
\end{tabular}

Dalam pengukuran parameter setiap variabel diberikan score dari yang terendah 0,2 sampai score yang tertinggi 1 yang nantinya data ini akan diolah dalam proses defuzifikasi.

Tabel 2. Bobot Kepentingan Variabel

\begin{tabular}{llr}
\hline \multicolumn{1}{c}{ Variabel } & Nama Kepentingan & Score \\
\hline Aplikasi & Penting & 0,75 \\
\hline Jaringan Merchant & Penting & 0,75 \\
\hline Promosi & Penting & 0,75 \\
\hline Premium Account & Penting & 0,75 \\
\hline Userfriendly & Sangat Penting & 1 \\
\hline Security & Sangat Penting & 1 \\
\hline
\end{tabular}

Sumber: Hasil Pengolahan Data (2020)

Dari tabel 2 bobot kepentingan variabel merupakan setiap variabel diberi score berdasarkan nama kepentingan contoh nama kepentingan cukup penting diberi score 0,5 sedangakan penting diberi score 0,75 dan yang terakhir sangat penting diberi nilai 1 .

Tabel 3. Nominasi Matriks

\begin{tabular}{llrrrrrrr}
\multicolumn{1}{c}{ Alternatif } & C1 & C2 & C3 & C4 & C5 & C6 \\
\hline Gopay & 4 & 5 & 5 & 5 & 5 & 4 \\
\hline Dana & 3 & 4 & 3 & 4 & 4 & 3 \\
\hline OVO & 5 & 4 & 5 & 4 & 5 & 4 \\
\hline Link Aja & 2 & 3 & 3 & 3 & 3 & 4 \\
\hline ShopeePay & 5 & 3 & 4 & 4 & 4 & 4 \\
\hline
\end{tabular}

Sumber: Hasil Pengolahan Data (2020)

Tabel 3 merupakan tahap ketiga data yang diperoleh dari kuisioner yang disebar oleh 12 mahasiswa pada Universitas Bina Insani. Range yang diperoleh dari nilai 1 sampai dengan 5 dengan kriteria 1 rendah dan 5 sangat baik lihat pada tabel 1 .

Tahapan keempat menghitung defuzzifikasi matriks dengan merubah nilai awal ke dalam bilangan fuzzy berdasarkan tabel 1. Contoh perhitungan alternatif Dana score fuzzy 0,6000 dengan C1. Kemudian perhitungan Alternatif Gopay, Dana, OVO, Link Aja dan ShopeePay terlihat pada nominasi matriks.

Normalisasi Matriks Alternatif Gopay dan C1

$r_{i j}=\frac{x_{i j}}{\sqrt{\sum_{i=j}^{m} x_{i j}}}=\frac{0,8000}{\sqrt{(0,6400+0,3600+1,0000+0,1600+0,1600+1,0000)}}=\frac{0,8000}{\sqrt{3,1600}}=0,4500$

Normalisasi Matriks Alternatif Dana dan C1

$r_{i j}=\frac{x_{i j}}{\sqrt{\sum_{i=j}^{m} x_{i j}}}=\frac{0,6000}{\sqrt{(0,6400+0,3600+1,0000+0,1600+0,1600+1,0000)}}=\frac{0,6000}{\sqrt{3,1600}}=0,3375$

Normalisasi Matriks Alternatif OVO dan C1

$r_{i j}=\frac{x_{i j}}{\sqrt{\sum_{i=j}^{m} x_{i j}}}=\frac{1,0000}{\sqrt{(0,6400+0,3600+1,0000+0,1600+0,1600+1,0000)}}=\frac{1,0000}{\sqrt{3,1600}}=0,5625$

Normalisasi Matriks Alternatif Link Aja dan C1

$r_{i j}=\frac{x_{i j}}{\sqrt{\sum_{i=j}^{m} x_{i j}}}=\frac{0,4000}{\sqrt{(0,6400+0,3600+1,0000+0,1600+0,1600+1,0000)}}=\frac{0,4000}{\sqrt{3,1600}}=0,2250$

Normalisasi Matriks Alternatif Shopeepay dan C1

$r_{i j}=\frac{x_{i j}}{\sqrt{\sum_{i=j}^{m} x_{i j}}}=\frac{1,0000}{\sqrt{(0,6400+0,3600+1,0000+0,1600+0,1600+1,0000)}}=\frac{1,0000}{\sqrt{3,1600}}=0,5625$ 
Tabel 4. Pembobotan

\begin{tabular}{lllllll}
\hline \multicolumn{1}{c}{ Alternatif } & C1 & C2 & C3 & C4 & C5 & C6 \\
\hline Gopay & 0,3375 & 0,4330 & 0,4092 & 0,4141 & 0,5241 & 0,4682 \\
\hline Dana & 0,2531 & 0,3464 & 0,2455 & 0,3313 & 0,4193 & 0,3511 \\
\hline OVO & 0,4219 & 0,3464 & 0,4092 & 0,3313 & 0,5241 & 0,4682 \\
\hline Link Aja & 0,1688 & 0,2598 & 0,2455 & 0,2485 & 0,3145 & 0,4682 \\
\hline ShopeePay & 0,4219 & 0,2598 & 0,3273 & 0,3313 & 0,4193 & 0,4682 \\
\hline
\end{tabular}

Sumber: Hasil Pengolahan Data (2020)

Kemudian tahapan kelima normalisasi matrik didapat dari tabel 2 bobot kepentingan $\mathrm{C} 1$ merupakan penting dengan score 0,75 berikut Perhitungan Pembobotan Fuzzy TOPSIS untuk C1.

$$
\begin{aligned}
y_{i j} & =w_{i j} \times r_{i j} \\
& =0,7500 \times 0,4500 \\
& =0,3375 \\
y_{i j} & =w_{i j} \times r_{i j} \\
& =0,7500 \times 0,3375 \\
& =0,2531 \\
y_{i j} & =w_{i j} \times r_{i j} \\
& =0,7500 \times 0,5625 \\
& =0,4219 \\
y_{i j} & =w_{i j} \times r_{i j} \\
& =0,7500 \times 0,2250 \\
& =0,1688 \\
y_{i j} & =w_{i j} \times r_{i j} \\
& =0,7500 \times 0,5625 \\
& =0,4219 \\
&
\end{aligned}
$$

Tahapan keenam solusi ideal positif dan negatif mencari solusi positif dengan cara jika kriteria memberikan keuntungan untuk perusahaan maka yang dicari adalah nilai tertinggi dari setiap kriteria dan sebaliknya jika kriteria memberikan biaya untuk perusahaan maka yang dicari nilai terendah dari setiap kriteria.

Tahapan ketujuh mencari alternatif positif dan negatif berdasarkan nilai solusi yang telah didapat dari rumus sebagai berikut dengan contoh perhitungan alternatif Dana dengan $\mathrm{C} 1$ lihat tabel 5.

Perhitungan Alternatif positif

$$
\begin{aligned}
D_{i^{+}} & =\sqrt{ } \sum_{i=j}^{m}\left(y_{i j}-y_{i j}\right)^{2} \\
& =0,4219-0,2531 \\
& =0,1688
\end{aligned}
$$

Perhitungan Alternatif negatif

$$
\begin{aligned}
D_{i^{-}} & =\sqrt{ } \sum_{i=j}^{m}\left(y_{i j}-y_{i j}\right)^{2} \\
& =0,2531-0,1688 \\
& =0,0844
\end{aligned}
$$

Tabel 5. Alternatif Positif dan Alternatif Negatif

\begin{tabular}{lllllllr}
\hline \multicolumn{1}{c}{ Alternatif Positif } & C1 & C2 & C3 & C4 & C5 & C6 & Total \\
\hline Gopay & 0,0844 & 0,0000 & 0,0000 & 0,0000 & 0,0000 & 0,0000 & 0,0844 \\
\hline Dana & 0,1688 & 0,0866 & 0,1637 & 0,0828 & 0,1048 & 0,1170 & 0,7237 \\
\hline OVO & 0,0000 & 0,0866 & 0,0000 & 0,0828 & 0,0000 & 0,0000 & 0,1694 \\
\hline Link Aja & 0,2531 & 0,1732 & 0,1637 & 0,1656 & 0,2097 & 0,0000 & 0,9653 \\
\hline ShopeePay & 0,0000 & 0,1732 & 0,0818 & 0,0828 & 0,1048 & 0,0000 & 0,4427 \\
\hline Alternatif Negatif & C1 & C2 & C3 & C4 & C5 & C6 & Total \\
\hline Gopay & 0,1688 & 0,1732 & 0,1637 & 0,1656 & 0,2097 & 0,1170 & 0,9980 \\
\hline Dana & 0,0844 & 0,0866 & 0,0000 & 0,0828 & 0,1048 & 0,0000 & 0,3586 \\
\hline OVO & 0,2531 & 0,0866 & 0,1637 & 0,0828 & 0,2097 & 0,1170 & 0,9129 \\
\hline Link Aja & 0,0000 & 0,0000 & 0,0000 & 0,0000 & 0,0000 & 0,1170 & 0,1170 \\
\hline ShopeePay & 0,2531 & 0,0000 & 0,0818 & 0,0828 & 0,1048 & 0,1170 & 0,6397 \\
\hline Sur
\end{tabular}

Sumber: Hasil Pengolahan Data (2020) 
Selanjutnya tahapan kedelapan menentukan nilai preferensi dari masing-masing alternatif negatif dan alternatif positif dengan menjumlahkan hasil dari setiap kriteria kemudian menentukan akar pangkat dan Membuat ranking keputusan, yang mendapat nilai tertinggi menjadi prioritas alternatif.

Perhitungan Preferensi

$$
V_{i=\frac{D_{i^{-}}}{D_{i^{-}}+D_{i^{+}}}} \quad=\frac{0,0844}{0,0844+0,1688}=\frac{0,0844}{0,2532}=0,3313
$$

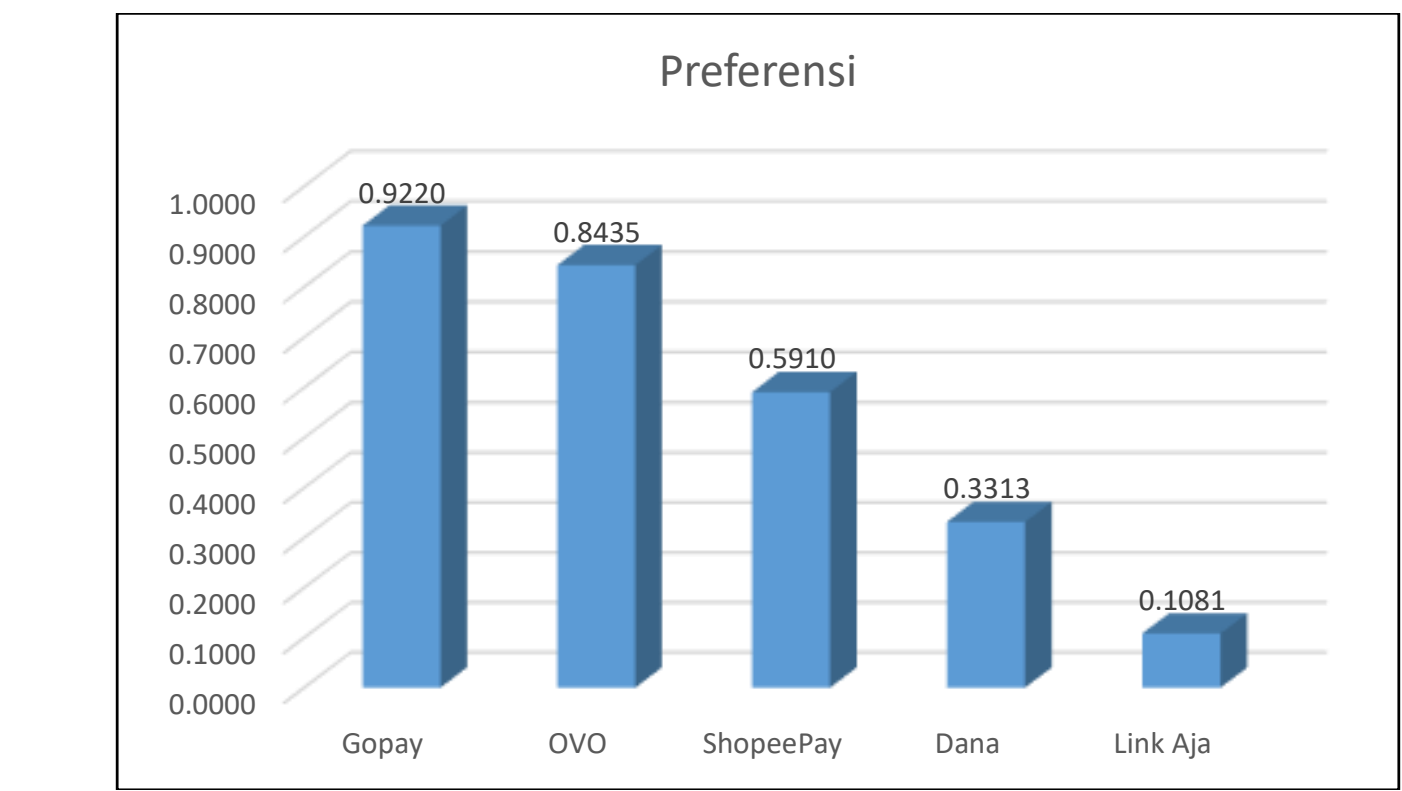

Sumber: Hasil Penelitian (2020)

Gambar 5. Preferensi

Langkah kedelapan dan yang terakhir menentukan perangkingan dari gambar 5 dapat terlihat nilai yang mendekati 1 yaitu gopay dengan angka 0,9220 peringkat 1 , kemudian peringkat kedua OVO dengan angka 0,8435 , selanjutnya peringkat ketiga Shopeepay dengan angka 0,5910 , kemudian peringkat keempat Dana dengan angka 0,3313 , dan peringkat kelima atau yang terakhir Link Aja dengan angka 0,1081.

\section{Kesimpulan}

Pada penelitian ini dapat disimpulkan fintech payment untuk mahasiwa menggunakan metode fuzzy Technique For Order Preference by Similarity of Ideal Solution (TOPSIS) dari 4 alternatif yaitu Gopay, Dana, OVO dan Shopeepay terpilih Gopay dengan nilai 0,9220 mendekati angka 1. Dengan adanya penelitan ini dapat menjadi rekomendasi mahasiswa dalam bertransaksi non tunai menggunakan fintech payment. Untuk penelitian selanjutnya diharapkan dapat dibuatkan sistem pendukung keputusan dalam bentuk prototype sehingga memudahkan dan cepat dalam memproses data.

\section{Referensi}

[1] Tim Elex Media, Mengenal Otoritas Jasa Keuangan dan Industri Jasa Keuangan - New. Jakarta: Elex Media Kompetindo, 2015.

[2] K. Budiarta, S. O. Ginting, and J. Simarmata, Ekonomi dan Bisnis Digital. Jakarta: Yayasan Kita Menulis, 2020.

[3] A. Rumondang, A. Sudirman, F. Effendi, J. Simarmata, and T. Agustin, Fintech: Inovasi Sistem Keuangan di Era Digital. Medan: Yayasan Kita Menulis, 2019.

[4] O. Sahroni, Fikih Muamalah Jilid 3 Membahas Persoalan Sosial dan Ekonomi Kekinian. Jakarta: Republika Penerbit, 2020.

[5] Program Studi Akuntansi, Fakultas Ekonomi dan Bisnis, and Universitas Ma Chung, Studi Kasus Sistem Informasi Manajemen: Volume 1, vol. 1, no. July. Malang: CV. Seribu 
Bintang, 2018.

[6] Program Studi Akuntansi and Universitas Ma Chung, Sistem Informasi Manajemen: Konsep dan Studi Kasus. Malang: Seribu Bintang, 2019.

[7] Bank Indonesia, "Statistik Sistem Pembayaran," 2020. [Online]. Available: https://www.bi.go.id/id/statistik/sistem-pembayaran/uang-elektronik/Contents/Jumlah Uang Elektronik.aspx. [Accessed: 10-Jun-2020].

[8] D. Nofriansyah, Konsep Data Mining Vs Sistem Pendukung Keputusan. Yogyakarta: Deepublish, 2014.

[9] D. Herawatie and E. Wuryanto, "Sistem Pendukung Keputusan Pemilihan Mahasiswa Berprestasi dengan Metode Fuzzy TOPSIS," J. Inf. Syst. Eng. Bus. Intell., vol. 3, no. 2, p. 92, 2017.

[10] H. Murtina, "Pengukuran Reliabilitas Menggunakan Pearson Correlation Pada Technique For Order Preference by Similarity of Ideal Solution ( TOPSIS )," vol. 2, no. 2, pp. 119128, 2018.

[11] Zuhri, "Penentuan Prioritas Perguruan Tinggi Negeri di Indonesia Menggunakan Metode Analisa Fuzzy Topsis," J. IIman, vol. 3, no. 1, pp. 50-60, 2015.

[12] B. Haqi, Buku Aplikasi SPK Pemilihan Dosen Terbaik Metode Simple Additive Weighting (SAW) Dengan Java. Yogyakarta: Deepublish, 2019.

[13] N. Duli, Metodologi Penelitian Kuantitatif: Beberapa Konsep Dasar Untuk Penulisan Skripsi \& Analisis Data dengan SPSS. Yogyakarta: Deepublish, 2019. 